\title{
Mae Fah Luang: Thailand's Princess Mother and the Border Patrol Police during the Cold War
}

\author{
Sinae Hyun
}

The mother of King Bhumibol Adulyadej, Princess Mother Sangwan, was the royal patron of the Thai Border Patrol Police (BPP) and an ardent supporter of its Cold War era civic action programmes. This article surveys the special relationship between the Princess Mother and the BPP and their development of royal projects among the highland minorities in northern Thailand to illuminate the implications of this collaboration for the spread of royalist nationalism and the evolving role of the monarchy from the 1960s to the present.

Upon hearing the loud helicopter propeller, the villagers begin to sit down on the hastily paved road, and the teachers from the Border Patrol Police (BPP, tamruat trawen chaidaen) school check the students lined up in the schoolyard for the last time. When the Royal Thai Police helicopter lands, a tiny old lady steps out to greet the BPP commanders, provincial governors, and other local politicians who have been awaiting her arrival. The lady and her entourage then walk quickly towards the school, leaving behind the villagers in their ethnic dress. The Princess Mother begins her royal duties by inspecting the school grounds along the designated route, officially opening school buildings, and distributing the gifts she has brought from the lowlands to the students and villagers. ${ }^{1}$ These are the scenes that created the legend of Mae Fah Luang, 'Royal Mother from the Sky'.

The mother of the late king Bhumibol Adulyadej, Her Royal Highness Princess Sinakharinthra (Somdet Phra Sinakharinthra Boromratchachonani née Sangwan Talapat), was a royal patron of the BPP, the paramilitary intelligence unit founded

Sinae Hyun is a Lecturer at the Department of History, University of Wisconsin-Whitewater. Correspondence in connection with this article should be addressed to: hyuns@uww.edu.

This article is based on the paper I presented at the panel 'Policing Thailand', Association for Asian Studies (AAS) conference, San Diego, 2013. I would like to thank the panel organiser, Duncan McCargo, and discussants; Thongchai Winichakul for comments and suggestions; and Will Shattuck for editing the paper. I am grateful to have had a chance to talk with the late Oliver Gordon Young (1927-2016) about his experience of working with the BPP and the United States Operations Mission (USOM) to Thailand in the 1960s.

1 This reconstruction of the Princess Mother's royal visit is based on my observation of Princess Sirindhorn's visit to a BPP school on 29 December 2010 and a number of archival photos and video clips collected during my field research in Thailand between 2009 and 2011.

2 This transcription follows the official English orthography used by the Mae Fah Luang Foundation. 
at the beginning of the Cold War. She was an ardent supporter of the BPP's 'civic action' programmes until her passing in 1995. This article examines the historical and political context of the Princess Mother's patronage of the BPP and its programmes targeting highland minorities in northern Thailand in particular. To understand the special relationship between the royal family and the BPP, and the subsequent transformation of the BPP from its origins as a United States Central Intelligence Agency (CIA)-backed counterinsurgency unit into a symbolic missionary of royalist nationalism, this survey focuses on three questions: First, in what context did the Princess Mother become the BPP's royal patron? Second, what were the shared objectives and consequent impacts of the BPP's civic action programmes and the Princess Mother's royal projects in northern Thailand during the Cold War? Third, what were the implications of the Princess Mother's projects with the BPP for the spread of royalist nationalism in Thailand, up to the present day?

I will argue that her sponsorship and participation in the BPP's programmes in the remote border areas during the Cold War played a pivotal role in generating the image of the late king Bhumibol as a benevolent, professional and modern monarch. The making of the 'development king' was a collective project of the royal family and royalist network who sought to enhance their political legitimacy and authority. The Princess Mother's support for the BPP in the early 1960s and dramatic expansion of her own projects among northern Thailand's highland minorities contributed to spreading the image of a professional monarchy and the idea of a royalist nationalism, thereby enabling the monarchy to enjoy irreproachable influence into the twentyfirst century.

\section{Border patrol police, 'My children'}

Before the 1960s the royal family had focused mainly on charitable activities. One of the earliest royal charities, the Ananda Mahidol scholarship, was launched in 1955 and awarded scholarships to medical students seeking advanced degrees abroad. In 1959, the programme evolved into the first royally sponsored organisation, the Ananda Mahidol Scholarship Foundation. ${ }^{3}$ The royals also made regular donations to other scholarships, as well as rural temples, hospitals and schools. By presenting themselves as generous donors to the poor and the alienated, the royal family attempted to establish the image of benevolent patrons of the nation. ${ }^{4}$

Still, the monarchy's attempts to make its presence and influence known to the general populace were rather limited in the 1950s. Since the People's Party coup in 1932 which overthrew the absolute monarchy, Thailand's royals remained in a feeble position amidst wildly changing politics with the rise of young military and civilian leaders and their quest for political modernisation. In particular, Field Marshal Phibun Songkhram, a key member of the People's Party, strove to reduce royal

3 Chanida Chitbundid, Khrongkan annueang ma chak phraratchadamri: kansathapna phrarat amnat nam nai phrabatsomdet phrachaoyuhua [The royally-initiated projects: The making of King Bhumibol's royal hegemony] (Bangkok: Foundation for the Promotion of Social Science and Humanities Textbooks Project, 2007), pp. 64-5; Bangkok Post, 'Six amazing decades', 12 June 2006, http://www.bangkokpost.com/60yrsthrone/amazing/index.html (last accessed 17 Apr. 2012).

4 Paul Handley, The king never smiles (New Haven, CT: Yale University Press, 2006), p. 122; Chanida, Khrongkan annueang ma chak phraratchadamri, pp. 62-87. 
influence in Thai politics. Several accounts argue that during his second premiership (1948-1957), Phibun was reluctant to let the king and queen travel outside Bangkok and be seen by the rural populace. ${ }^{5}$ The first official royal trip to the northeast in 1955 under the close watch of Phibun was akin to the traditional Siamese royal journey called sadet praphatton, where the king would travel incognito to 'see his country in "normal" circumstance without any preparation as for royal visits'. 6

Only after the Commander of the Thai Army Sarit Thanarat came to power in 1957 by staging a coup against the Phibun administration could King Bhumibol and Queen Sirikit gain control over their travels outside Bangkok. ${ }^{7}$ The royal couple made two official visits - to the north in 1958 and the south in 1959 - and many other unofficial trips to royal residences in the provinces soon after. However, their itineraries did not go beyond the traditional grand procession in the countryside or the receiving of guests in provincial royal residences. ${ }^{8}$

One notable difference between the royal journeys in the nineteenth century and those of the mid-1950s, however, was the royal family's voluntary exposure of their identity. Whereas the sadet praphatton took place in disguise, the royal visits or kan sadet from the 1950s onward were made for the public. Indeed, the kan sadets were reproduced in millions of photographs and on film and released for public consumption, which contributed tremendously to enhancing the royal family's popularity. ${ }^{9}$ In this way, the leisurely royal trips were transformed into a kind of intentional public event from the mid-1950s to demonstrate how the royal influence stretched out to the rural and border areas.

The royal family's first informal meeting with the BPP in the early 1950s took place during one of their unofficial trips to Hua Hin, where the young royal couple had spent their annual wedding anniversary vacation since their return to Thailand in 1951. The royal family became interested in the BPP at a time when the directorgeneral of the Thai National Police Department (TNPD) Police General Phao Siyanon was rising to power, and the US government was actively providing aid to turn the BPP and a police paratrooper company that came under the BPP organisation in 1960, the Police Aerial Reinforcement Unit (PARU), into an elite paramilitary force. Both the BPP and PARU were set up by the Phibun administration and the CIA in 1951 to gather intelligence and conduct unconventional warfare in Thailand's remote border areas. James William Lair (Bill Lair), a CIA operative

5 Handley, The king never smiles, pp. 120, 127; Murray Fromson, 'The King and Marshal Sarit', Associated Press, 17 Sept. 1957, reprinted in Foreign Correspondents' Club of Thailand (FCCT), The King of Thailand in world focus: Articles and images from the International Press, 1946-2006 (Singapore: Editions Didier Millet, 2007), p. 46; King Bhumibol Adulyadej: A life's work, ed. Nicholas Grossman and Dominic Faulder (Singapore: Editions Didier Millet, 2011), pp. 106-7.

6 Thongchai Winichakul, 'The others within: Travel and ethno-spatial differentiation of Siamese subjects 1885-1910', in Civility and savagery: Social identity in Tai states, ed. Andrew Turton (London: Curzon Press, 2000), p. 44.

7 Thak Chaloemtiarana, Thailand: The politics of despotic paternalism (Ithaca, NY: SEAP, Cornell University, 2007), pp. 205-6; Handley, The king never smiles, pp. 143-5.

8 Prakan Klinfung, 'Tam roi phrayukhonlabat: kansadet phraratchadamnoen chonabot kap kantotan communit' [In His Majesty's footsteps: Royal visits to the provincial areas and anticommunism], $\mathrm{Fa}$ Diao Kan 6, 4 (2008): 179-83.

9 Handley, The king never smiles, p. 143. 
assigned to train the BPP and founder of PARU, fondly remembered his informal relationship with the king in the early 1950s.

Lair was training PARU members in the grounds of Mareutkhathayawan Palace, which is located by the sea near Hua Hin, when a royal aide approached him and said that the king wished to have a boat race with him. Shortly after, the king and Lair raced on sailboats by the palace, eventually becoming close friends. Upon learning that the king was interested in range shooting, Lair prepared a shooting ground in PARU's Naresuan Camp, located right across the Klai Kangwon Palace in Hua Hin, where the king could walk to the camp freely and practise shooting with Lair and PARU members. ${ }^{10}$ Impressed by the king's sincere, intimate friendship, Lair promised the king that if something were to happen and the king could not get out of the country, PARU would take him to a safe place. ${ }^{11}$ Lair added that the Princess Mother had also informally visited the PARU camp in Hua Hin while she was staying with the royal family at Klai Kangwon Palace. ${ }^{12}$ In short, the royal family, including the Princess Mother, was acquainted with the BPP and its activities through the CIA and Phao Siyanon from the early 1950s.

Meanwhile, the BPP launched its first official civic action programme called 'Development and Aid for Hill Tribe People and People Far from Communication' under the auspices of the Ministry of Interior in $1956 .{ }^{13}$ Since the CIA and Phao Siyanon created the BPP and PARU as the frontline paramilitary force for guerrilla fighting, intelligence gathering and psychological operations in the remote border areas, the early civic action programmes should be understood along the lines of this original goal. The BPP and PARU were set up mainly to collect information about enemy infiltration and attacks and also to befriend the people in these areas to conduct their intelligence work more efficiently. Building a close relationship with the highland minorities was also crucial for creating a reserve force in case of war. If the provision of medical treatment and daily goods were to win the border people's hearts and minds, the establishment of schools and the deployment of patrol police were intended to expand intelligence gathering, civilian counterinsurgency and surveillance in these remote areas.

All these activities were briefly halted by Sarit's coup in 1957. Although the BPP was demoted to being under the Provincial Police, and thus deprived of its institutional autonomy, it was not disbanded. The BPP survived the crisis mainly because of its timely shift of operational focus from military to civilian counterinsurgency. Expecting that this shift to civilian policing would reduce the army's suspicion of its military strength, the BPP continually appealed to Sarit and other military factions to recognise the contributions of its civic action programmes to the strengthening of national border surveillance.

10 Interview with James William (Bill) Lair, 14-16 Feb. 2013.

11 The Vietnam Archive Oral History Project: Interview with Bill Lair, conducted by Steve Maxner, 12 Dec. 2001; http://www.vietnam.ttu.edu/oralhistory/Transcripts/Lair_Bill.htm (last accessed 2 Sept. 2015), p. 70 .

12 Interview, Bill Lair, 16 Feb. 2013.

13 See Soem Yakhasem, 'Rueang tamruat trawen chaidaen, mokarakhom 2521' [The BPP story, January 1978] (ms, 1978), pp. 39-40; and a bilingual report, BPP Headquarters (BBP HQ), Kan songkhro chaopa chaokhao lae prachachon klai khamanakhom / Aid given to hill tribe people and people far from communication (Bangkok: BPP HQ, 1956). 
However, the desired recognition did not come from Sarit's regime. The BPP's survival was due to other powers in the early 1960s: the United States Overseas Mission (USOM) and the royal family. Just as the CIA did not cease its financial and advisory assistance to the BPP after Sarit's coup, so, too, the king and queen had continued to visit the BPP and demonstrate confidence in its existence. In the meantime, the BPP's expanding programmes alongside the United States' burgeoning rural development projects in Thailand seemed the right place to make a fresh start for this young, vulnerable royal couple who hoped to win the hearts and minds of the Thai populace. The Princess Mother, in particular, began publicly sponsoring the BPP's civic action programmes in 1962 in support of the royal couple. Indeed, it was the Princess Mother who took the lead in transforming the royal family's friendly relationship with the BPP into a professional collaboration. The Princess Mother's sponsorship and subsequent participation in the BPP's programmes thus should be understood not only as a royal obligation to help the people in the margins, but also as a strategic decision to deepen the royals' image as the nation's legitimate rulers.

The Princess Mother's choice of the BPP as her right-hand force might have also represented the monarchy's general desire to reinforce its fragile institution against the fierce competition among the generals by having an elite, but seemingly apolitical, force on their side like their predecessors. In competition with the Thai army in 1911, King Vajiravudh, for instance, initiated his private Wild Tiger Corps (suea pa), which served as an armed force for safeguarding royalist nationalism and the monarchy. ${ }^{14}$ The BPP might have been expected to play the same role for the still politically insecure royal family. ${ }^{15}$

Although King Bhumibol did not create the BPP, his ties with the paramilitary enabled certain advantages. The unit was well furnished with American armaments and financial support, but after 1957 it lacked an actual caretaker when Phao Siyanon left Thailand. The small force was manageable, inconspicuous and set up for unconventional warfare and civilian counterinsurgency. ${ }^{16}$ Besides, the BPP's programmes had been further expanded with USOM's aid and improved with accumulated experience and knowledge about border areas and people. In sum, the Princess Mother regarded the BPP as a good candidate for a private royal force both because of the United States' support and for the BPP's relatively apolitical, inconspicuous stance. In this regard, her sponsorship can be seen as a strategic decision by the Princess Mother to reinvigorate monarchical power and influence over the Thai nation-state.

14 Thongchai Winichakul, Siam mapped: A history of the geo-body of a nation (Honolulu: University of Hawaii Press, 1994), p. 167.

15 On the political role of the Wild Tiger Corps, see Eiji Murashima, 'The origin of modern official state ideology in Thailand', Journal of Southeast Asian Studies 19, 1 (1988): 91.

16 In an address to the BPP in Chiang Mai in late 1970, the king said that despite being small, the BPP and PARU were popular, and could control and earn the people's trust. 'Phraboromratchowat khong phrasomdetphrachaoyuhua: phraratchathan ke nai tamruat trawen chaiden na kongkamkapkan tamruat chaiden khet 5 khai dararatsami amphoe maerim changwat chiangmai muawanpharuehat thi 24 thanwakhom pho. Soe. 2513' [Royal guidance from His Majesty for the BPP in BPP Area Division 5, Dararatsami Camp, Amphoe Maerim, Chiang Mai province, Thurs. 24 Dec. 1970], in BPP HQ, Sisippi rongrian tochodo [40 years of the BPP schools] (Bangkok: BPP HQ, 1996), pp. 6-7. 
Secretary General of the Chaipattana Foundation Dr Sumet Tantivejkul, who has been one of the royal family's closest aides and the one most linked to their development projects, remarks that the true kingmaker was the Princess Mother Sangwan. He recalled that the Princess Mother always taught King Bhumibol to 'be a hero to those less fortunate than himself. ${ }^{17}$ Born a commoner, she lost both her parents and her siblings before the age of ten and had to rely on her relatives to survive. Luckily she learnt to read and write, and eventually was selected for the nursing and midwifery school at Siriraj Hospital at the age of thirteen. When she turned seventeen, she received a scholarship which was sponsored by the Queen Grandmother Sawang Wathana and moved to the United States to further her education in nursing. When she travelled to Boston in 1918, she met Prince Mahidol Adulyadej who was studying medicine there; a year later, they received a royal endorsement for their engagement. They had a daughter and two sons, who later became the eighth and ninth kings of the Chakri dynasty. Prince Mahidol died in 1929 after suffering from kidney problems for years. The Princess Mother's hardships - which were compounded by the death of her elder son, King Ananda Mahidol, in a tragic accident in 1946 - made her stronger. She had to protect her other son, who became the ninth monarch of the Chakri dynasty, Bhumibol Adulyadej, from the possible collapse of the monarchy in the wake of Thailand's political upheavals. ${ }^{18}$

While living in Switzerland, the Princess Mother began spending winters in Thailand from the early 1960s. The royal residence in Chiang Mai, Bhubing, had been promoted to royal palace status in 1962 and became her favorite place to stay. Although the Princess Mother had met some BPP members in the 1950s, the organisation's official account dates their relationship to 1962, the year she launched her official support for the BPP alongside another key patron which will be discussed later, the USOM's Public Safety Division.

The BPP states that the first encounter between the Princess Mother and BPP took place in Bhubing. When Princess Mother Sangwan was on vacation there between 15 September and 3 October 1962, she took a detour and walked all the way to the palace's back gate, where she saw several men in military fatigues. She asked one of the men where they were from. BPP platoon commander Police Colonel Praphan Yuktanon from BPP Area Division 5 Camp answered that he was a border policeman. She responded to him: 'Border Police? I thought that you were from one of the army units.' Intrigued by this brief encounter, she called on the BPP commanders to learn more about their work and decided to support the BPP's civic action programme shortly thereafter. ${ }^{19}$ Soon, the Princess Mother emerged as the BPP's primary royal sponsor and played a crucial role in attracting favorable public attention to the BPP and the royal family in the early 1960s.

Thus began a long and close relationship with the BPP. The Princess Mother would often call individual BPP officials and patrolmen 'my child (luk)' or 'grandchild (lan)' and her continual travels and warm relationship with the unit gave rise to another popular nickname for the Princess Mother, 'somdetya', the royal paternal

17 Quoted in Bangkok Post, 'Six amazing decades'.

18 Handley, The king never smiles, pp. 54-7, 81-3.

19 BPP HQ, Tochodo sadudi 100 pi somdetya [The BPP honours the hundredth anniversary of the birth of the Princess Mother] (Bangkok: Chulalongkorn University Press, 2000), pp. 3-5. 
grandmother. This remains the most popular term for her among the general public. ${ }^{20}$ It was also the Princess Mother's own idea to wear the BPP fatigues and beret whenever she travelled to the border areas. Notably, she added a horse-riding whip to her BPP uniform to show her longtime hobby, while hinting at the image of an ethnic minority female warrior in the northern Thai-Burmese border who dressed in military fatigues called nang suea han (brave female tiger). ${ }^{21}$

Another anecdote regarding the close relationship between the Princess Mother and the BPP comes from the history of the Princess Mother's Medical Volunteer (PMMV) Foundation. When the Princess Mother was staying in Bhubing Palace in 1964, she visited several BPP camps in the hill areas and noticed the poor living conditions of both the patrolmen and the villagers; the BPP members were also more vulnerable to endemic disease in the jungles. In February 1969, she invited doctors and nurses from Bangkok to Bhubing Palace and asked if they would be willing to volunteer to provide medical services in the remote highland jungles. This was the beginning of the Volunteer Flying Doctor Units (known as the PMMV after 1985), established under royal patronage in $1969 .{ }^{22}$ All these stories suggest that she was indeed 'more than a parent to the Border Patrol Police'. ${ }^{23}$

The Princess Mother's support for the BPP went well beyond simply bringing donations and gifts. By partaking in the BPP's civic action programmes, the royal family promoted the image of the monarchy as the benevolent patron of the Thai nation. Through her endeavours to bring development and modernisation to the highland minorities, she styled herself as the royal mother of the marginalised, which eventually gave rise to another popular title, Mae Fah Luang, the Royal Mother from the Sky. ${ }^{24}$ The BPP, in turn, gained much from the Princess Mother because her direct patronage endowed the unit with greater prestige than any other governmental organisation. In this regard, the expansion of BPP's civic actions under the Princess Mother's patronage and the subsequent expansion of her royal projects was mutually beneficial for both the BPP and the monarchy.

\section{The working mother}

The signs of Bhumibol's transformation from a traditional ruler to a professional, modern nation-builder became clearer from the early 1960s. In this regard, it is important to examine more closely the Princess Mother's decision to sponsor the BPP's projects in 1962. The BPP's official history tell us that Sarit's coup in 1957 contributed to the cessation of American support for the unit, which was on the brink of disbandment. ${ }^{25}$ In fact, the CIA's funding and advice to the BPP did not cease but, to

20 Personal communication, former member of PARU, 27 Apr. 2010; 'Tha song pen ying kua bidonmanda tamruat trawen chaidaen' [She was more than a parent to the BPP], Cop's Magazine 2, 14 (2007), p. 6 .

21 Cop's Magazine, 'Tha song pen ying kua bidonmanda', p. 5.

22 Yongyut Satchawanit, 'Phet asa khong somdetya' [Princess Mother's medical volunteers], Warasan pho-o-sowo [PMMV Magazine] 9 (Oct. 1995-Oct. 1996), pp. 63-4.

23 Cop's Magazine, 'Tha song pen ying kua bidonmanda', p. 4.

24 Dora H. Layton, 'Royal Mother from the Sky', Sawaddi, Jan. 1968, pp. 6, 20.

25 Chan Angsuchot, 'Phuean tamruat trawen chaidaen lae tamruat phonrom thi rak thang lai [Dearest friends - the BPP and PARU]', in Kong banchakan tamruat trawen chaidaen thiraluek nai kanpoet akhan bocho tochodo, 7 phruetsaphakhom 2518 [Commemorative volume marking the opening of the 
reduce the Thai army's suspicions and hostility, it used a different channel to continue its assistance. After the US Agency for International Development (USAID) was established by the Foreign Assistance Act in late 1961, a regional office, the US Operations Mission (USOM) to Thailand, was set up to take over the mission of its predecessor in providing aid to developing countries, the US International Cooperation Administration (ICA). USOM-Thailand's officials, were however mostly transferred from the ICA and the CIA, and well informed about the BPP's projects in the remote border areas and its operational capability.

USOM's decision to support BPP's civic actions in the early 1960s was a strategic one, continuing from the earlier American agencies' involvement. ${ }^{26}$ In particular, USOM's Public Safety Division (PSD) wanted to take advantage of the BPP's existing border programmes, which had in fact been conceived and developed with the CIA specifically for counterinsurgency and surveillance purposes. The BPP had already built more than sixty schools and unit members were deployed widely in the border areas as teachers and development platoon officers. In other words, the CIA resumed its counterinsurgency operations in Thailand under the guise of PSD advisers and soon gained control of the BPP's civic action programme. ${ }^{27}$ Accordingly, changes began in 1962. The PSD supported the BPP's highland minority aid project from fiscal year 1962, naming it the 'Remote Area Security Development' programme and focusing on improving elementary education, medical assistance, village development, economic promotion, youth activities and counterinsurgency operations. ${ }^{28}$ The projects were divided into five fields of operation: education, health and sanitation, community and rural development, village security and narcotics suppression. It should be noted that the Princess Mother began collaborating with the BPP from 1962 when the BPP and PSD began working together. She participated in all five fields of BPP-PSD civic actions; just a brief review of the key projects that eventually gave birth to the Princess Mother's royal projects will suffice to understand the effect of her sponsorship.

One of the most well-known of these was the abovementioned Volunteer Flying Doctor Units, which was renamed after the Princess Mother donated one million baht (US\$36,298) in 1985 to reestablish it as a royally sponsored foundation. ${ }^{29}$ The Flying Doctor/PMMV project had been carried out by a volunteer group of medical

BPP HQ building, 7 May 1975] (Bangkok: BPP HQ, 1975), pp. 60-62; Thomas D. Lobe, United States national security policy and aid to the Thailand Police (Denver: University of Denver, Graduate School of International Studies, 1977), pp. 28, 39; Daniel Fineman, A special relationship: The United States and military government in Thailand, 1947-1958 (Honolulu: University of Hawaii Press, 1997), p. 181; Kenneth J. Conboy, Shadow war: The CIA's secret war in Laos (Boulder, CO: Paladin, 1995), p. 58. 26 See Marvin J. Jones and Philip D. Batson, 'A brief history of USOM support to the Thai National Police Department' (Bangkok: Public Safety Division, USOM, Aug. 1969); US Agency for International Development, 'USOM in perspective' (Bangkok: USOM, Sept. 1971); Rey M. Hill, 'An overview of USAID participation in the Thailand programs of development and security, 1951 to 1973' (Bangkok: USOM, Aug. 1973); USOM, 'Aid program in Thailand' (n.p., Bangkok, Jan. 1968). See also Thomas D. Lobe, 'U.S. police assistance for the Third World' (PhD diss., University of Michigan, Ann Arbor, 1975), pp. 330-31.

27 Lobe, 'U.S. police assistance for the Third World', pp. 334-5.

28 Raymond Coffey, 'Thailand: Public safety/ Border Patrol Police Remote Area Security Development:

An approach to counterinsurgency by the Border Patrol Police' (Bangkok: USOM, Apr. 1971), p. 2.

29 Yongyut, 'Phet asa khong somdetya', pp. 63-4. 
professionals from major towns in Thailand since 1969. The volunteers would travel to remote areas by helicopter during weekends to offer medical treatment to the villagers. The target villages were determined by the BPP, and the trips were also arranged by the unit. In its first year 2,850 professionals volunteered. ${ }^{30}$ In that year, the PMMV coordinated with BPP officers in Area Division 5 Camp in Chiang Mai and selected 42 villages in northern Thailand to visit. Shortly thereafter, 20 PMMV local branches were set up in Thailand's border areas in the first year; between 1969 and 1982, this number grew to 48. ${ }^{31}$ The king also commanded royal medics to treat highland minority patients in over 40 villages in Chiang Rai and Nan provinces from the late 1960s in support of the PMMV. ${ }^{32}$

The royal family also initiated a project called 'Bordercraft' in 1965 to promote cottage industries among the ethnic minorities. ${ }^{33}$ According to the BPP's account, the project was initially launched when King Bhumibol donated 10,000 baht to the BPP to establish the 'Centre for Promoting the Hill Tribes Crafts under Royal Support' in Chiang Mai to increase alternative sources of cash income for the minority groups in place of opium cultivation. In addition, the project was intended to expedite the highland minorities' exposure to the market system in the lowlands, and to increase their communication and experience with Thais. ${ }^{34}$ In the beginning, village women of seven ethnic groups - Hmong, Yunnanese migrants, Karen, Akha, Lahu, Tai Lue, and Lisu - from the 17 northern provinces were trained and employed under this project. USOM provided advisory services and partial funding for the project between 1967 and 1968, but not long after the American advisers left, the Princess Mother lent 30,000 Thai baht to the BPP to continue the project. ${ }^{35}$ Between 1965 and 1974, over 2,000 highland minority women from 50 villages came to participate in the project under the command of Area Division 5 Camp in Chiang Mai. ${ }^{36}$ In January 1980, the project finally became an official project, and the Centre became the 'Thai Hill Tribe Products Promotion Foundation under Royal Support'. The Bordercraft project became a forerunner of the Mae Fah Luang Foundation.

The Princess Mother was also well aware of the deteriorating security conditions in the north. Witnessing the rapid increase of insurgency among highland minorities in northern Thailand around 1967-1968, when the Viet Minh's struggle against the United States intensified in neighbouring countries, the BPP initiated a military training programme, the 'Hill Tribe Volunteers Team', to set up village self-defense units. The first round of training began in September 1968 at Mae Taeng training camp in

30 Betty Dumaine and Dora H. Layton, Somdetphra boromratchachonani / The Princess Mother (Bangkok: Thai Watana Panich, 1972), p. 137.

31 Yongyut, 'Phet asa khong somdetya', p. 65. The number of branches was compiled from the PMMV Foundation website, www.pmmv.or.th (last accessed 3 Sept. 2015).

32 Manas Khantatatbumroong, 'Khrongkan phathana phuea khuammankhong' [Development for security project] (BPP internal report, 1975), p. 6.

33 Bordercraft is also known as the 'Hill Tribe Handicraft Programme'.

34 'Sunsongsoem phlitphan chaokhao nai phraboromratchanukhro' [Centre for the promotion of hill tribes crafts under royal support] (BPP internal report, n.d.), p. 5.

35 'Sunsongsoem phlitphan chaokhao nai phraboromratchanukhro', p. 1; USAID, Office of Public Safety, 'Termination phase-out study, Public Safety Project, Thailand' (Washington, DC: USAID, 1974), p. 39.

36 Manas, 'Khrongkan phathana phuea khuammankhong', p. 9. 
Chiang Mai province. ${ }^{37}$ Its primary goal was to supplement the shortage of BPP manpower with hill tribe people. ${ }^{38}$ Subsequently, PSD and the Thai Communist Suppression Operations Command joined the programme, and the project was officially established with a new title, 'Border Security Volunteer Teams' (BSVT) in September $1969 .{ }^{39}$

Despite the BPP's high expectations for the BSVT project, the Thai government withdrew its funding in 1975, while the PSD had officially withdrawn in 1973. The central reason why the Thai government had to terminate its financial support for the project was because it could not fully trust the ethnic minorities, whose national allegiance seemed to remain ambivalent. ${ }^{40}$ At this stage, it was the Princess Mother who found the funds for food and training to support the BPP and sustain the project. ${ }^{41}$

Generally speaking, one notable disparity between the Thai government's rural development programmes and those initiated by the Princess Mother, the BPP and USOM, as observed in the above cases, was their coverage. The Princess Mother and the BPP, with generous financial and technical support from the PSD, launched and experimented with various rural development programmes in northern Thailand first, and then extended their initiatives to other regions. From its official foundation in 1969, for instance, the PMMV's offices spread throughout Thailand. The Thai government's rural healthcare programme did not expand beyond the northern and northeastern regions because the project was tied to the provinces where the government's Accelerated Rural Development programme was carried out. These provinces were considered to be 'sensitive areas' by the US and Thai governments. While the BPP and royal projects were building their public bases at all Thailand's borders, the US and Thai military governments' rural development programmes limited their operations to areas they felt faced imminent security threats.

Similarly, the Princess Mother's initial community development projects, including 'Bordercraft', focused on northern Thailand at first, but soon expanded to other regions. One distinctive rural development project that had resembled the USOM and BPP's Key Villages programme was launched in Kalasin province in northeastern Thailand under the title 'Building Security in the Rural Villages Project under the Princess Mother's Royal Patronage'.42 Proposed by Police General Wiphat Wipunlakorn, a former Commissioner of the BPP in 1977, the

37 Jeffrey Race, 'The war in northern Thailand', Modern Asian Studies 8, 1 (1974): 85-112.

38 Phairot Pusayanawin, 'Somdetya kap kansakatkan kankhayai itthiphon khong phak khommunit haeng prathet thai' [Special essay: Princess Mother and the interception of the Communist Party of Thailand's influence], Tamruat trawen chaidaen parithat [Border Patrol Police Review] 11, 41 (Oct. 1995-Jan. 1996): 58-9.

39 Phairot, 'Somdetya kap kansakatkan kankhayai itthiphon', p. 59; USAID, 'Termination phase-out study', p. 39.

40 Robert M. Hearn, Thai government programs in refugee relocation and resettlement in northern Thailand (Auburn, NY: Thailand Books, 1974), p. 26.

41 BPP HQ, 'Khrongkan sang khuammankhong nai chonabot thi muban nai phra upatham somdetphra sinakharindra boromratchachonani (somobo tochodo sowo)' [Building security in the rural villages project under the Princess Mother's royal patronage], in Anuson phon tamruat ek wipunlakon [Cremation volume, Police General Wiphat Wipunlakon], ed. BPP HQ (Bangkok: Chulalongkorn University Press, 2005), p. 85.

42 BPP HQ, Anuson phon tamruat ek wiphat wipunlakon, p. 83. 
project finally joined the list of royal projects under the Princess Mother's patronage in 1981.

The 'Building Security in the Rural Villages Project' primarily aimed at inserting the BPP's development-for-security objectives into village-level governance and community activities and thus the BPP members first conducted research on the environmental, political, economic and social conditions in remote northeastern villages. ${ }^{43}$ This project aimed to propagate ideas about 'democracy under constitutional monarchy' (prachathipatai an mi phramahakasat pen pramuk) among the rural villagers through collective community activities. ${ }^{44}$ The Princess Mother donated 1.35 million baht (US\$64,286) in June 1981 and soon influential Thai businessman Suwit Osothanukhroe donated another 2.65 million baht (US\$126,190) to the BPP to increase the project's coverage. Consequently, it was extended to Khon Kaen, Ubon Ratchathani, Sisaket, Loei, Phetburi and Tak provinces. ${ }^{45}$ After her death in 1995, the project changed its primary mission statement to 'commemorate the royal charity activities of the Princess Mother'; by 2005 the project had extended to 173 villages in northern and northeastern Thailand. ${ }^{46}$

The BSVT project similarly survived after both the Thai and US governments stopped funding it because of the Princess Mother's sponsorship. In the latter half of the 1970s, these BSVT members were mobilised in the Princess Mother's 'Building Security in the Rural Villages Project' in northeastern Thailand. ${ }^{47}$ With the Princess Mother's aid and encouragement, the BSVT project expanded to other regions along with the BPP's new rural development projects, with 43 teams in mid-1990. ${ }^{48}$

As with her medical project, the Princess Mother's rural development project extended to the border areas and rural villages throughout Thailand alongside the BPP. Simply put, it could be said that wherever the BPP went, royal projects followed. As a result, the Princess Mother's and BPP's development projects continued to expand to the remotest corners of Thailand, garnering rural people's appreciation for the royal family, while similar projects of the Thai military regimes neither contributed to the expansion of rural social welfare nor enhanced the image of government as the caretaker of the people.

The expansion of the Princess Mother's royal projects alongside the BPP's also reveals another important agenda of reinvigorating the royal family's legitimacy through creating the image of a modern, professional monarchy. From the mid1950s, the BPP's focus on narcotics suppression constituted a central justification for their other programmes among the minorities in northern Thailand. In 1959, Sarit declared an official ban on opium, demolished the opium shops and dens in

43 Ibid., pp. 83-5.

44 Ibid., pp. 84, 86.

45 Ibid., p. 85.

46 Ibid., p. 86.

47 Ibid., p. 85.

48 Interview with Manas Khantatatbumroong, 26 May 2010; Phairot, 'Somdetya kap kansakatkan kankhayai itthiphon', pp. 60-61. Police Major General Manas Khantatatbumroong was a former deputy commissioner of the BPP Headquarters in 1991-1992. 
Bangkok in June, and passed the 'Harmful Habit-Forming Drugs Act' in October. ${ }^{49}$ Sarit was pressured by the US government, which believed that the Chinese communist involvement in the opium business supported its prolonged struggle. ${ }^{50}$ The US government also suspected that the Thai military had come to rely increasingly on this lucrative 'repellent business', especially after Sarit's anti-corruption campaign, which drained the generals' revenues and their side incomes. Instead of trying to persuade the Thai military, the US government tackled the problem with evidence that opium 'passing through or originating in Thailand was reaching the United States', thereby causing far deeper concerns at home. ${ }^{51}$

Sarit's antinarcotics programme transformed opium into a political weapon for strengthening his legitimacy from the late 1950s, consequently enhancing royal legitimacy. As discussed extensively by Thak Chaloemtiarana in The politics of despotic paternalism, Sarit promoted the revival of traditional leadership centred on the Thai monarchy and, in return, the royal family endorsed Sarit's dictatorship. ${ }^{52}$ At the same time, King Bhumibol began befriending other military leaders to strengthen his power base against the democratic civilian leaders, particularly the group that had ended the absolute monarchy in 1932. There is one good example that shows how these power dynamics among the military, civilian leaders and monarchy finally led the royal family to step into a symbolic opium war.

In the late 1980s, the Princess Mother initiated a royal project called the Doi Tung Development Project in Chiang Rai province, which included the building of a museum, the Hall of Opium. The museum highlights the history of the Sarit regime's antinarcotics stance in direct contrast to its predecessors: 'The 1932 political reform in Thailand not only continued opium trade in Thailand, but also expanded the government's role by promoting opium growing in the northern part of the country.' ${ }^{53}$ After Sarit's death, King Bhumibol and the royal family actively mobilised the anti-opium campaign by promoting alternative agricultural crops and trade among the highland minorities, which finally led to launching their own development project for the highland minorities in 1969. From then on, almost all royal support for the BPP and its projects in northern Thailand was justified and also publicised as a movement against opium cultivation. Over the years, the royal family was seen as playing a leading role in bringing the non-Thai people along the border to civilisation and modernisation to protect them from primitiveness as well as communism.

In this context, the non-Thai highland minorities were viewed as potential enemies of the state under the US-Thai counterinsurgency strategy because they

49 'Harmful habit-forming drugs Act B.E. 2502', United Nations Office on Drugs and Crimes (UNODC) online archives, https://www.unodc.org/doc/enl/1960-118.pdf (last accessed 5 May 2016).

50 See, for example, Central Intelligence Agency, 'An examination of the charges of Chinese Communist involvement in the illicit opium trade' (Secret Intelligence Memorandum, CIA, Office of Research and Reports, 9 Nov. 1956). See also Alfred W. McCoy, The politics of heroin: CIA complicity in the global drug trade, rev. ed. (Chicago: Lawrence Hill, 2003), pp. 127-92, 283-386.

51 'Letter from the Ambassador in Thailand (Johnson) to the Director of the Office of Southeast Asian Affairs (Kocher), Bangkok, June 19, 1959', in Foreign relations of the United States, 1958-1960: South and Southeast Asia, vol. 15, ed. United States Department of State (Washington, DC: U.S. Government Printing Office, 1992), pp. 1079-80.

52 Thak, Politics of despotic paternalism, pp. 97-8.

53 Exhibit caption, Hall of Opium, 21 May 2011. 
were believed to be communist sympathisers, some owing to their ethnic Chinese heritage and others due to their lack of a sense of belonging to the Thai nation-state, which was believed to make them more vulnerable to communist infiltration. Additionally, their long involvement in opium cultivation was seen as the source of insurgencies and security problems. The Hmong and Mien in particular received the most attention from the CIA and the BPP during the Cold War, both for their reliance on opium cultivation and their proven jungle fighting capability. ${ }^{54}$ The Thai monarch's promotion of the antinarcotics campaign was therefore expected to achieve both objectives: to prevent these highland minorities from growing and trading opium; and to assimilate them by instilling the importance of abandoning opium cultivation, which was an anti-Thai tradition.

In this process, the project for assisting the highland minority called the 'Royal Hill Tribe Development Project', launched in 1965, became the foundation of the present Royal Project (khrongkan annuang ma chak phraratchadamri, popularly known as khrongkan phraratchadamri). ${ }^{55}$ In his address at a Rotary Club Gala Dinner on 27 February 1969, the king explained why the royal project for aiding the highland minorities was significant. He reasoned

firstly, to give help to fellow men; secondly, to prevent and combat subversion by raising the standard of living of these people; and thirdly, to preserve national wealth and renown such as [to] prevent forest destruction and to halt traffic of narcotics, which has disastrous consequences for the country. ${ }^{56}$

In retrospect, his explanation somewhat echoes that of the BPP and sponsoring US agencies more than a decade earlier. The king similarly saw that remote area development projects would strengthen national security as well as expedite the national consolidation of marginalised border areas and people. At the same time, the development projects offered a more justifiable power basis for the young monarch. In this respect, the actual accomplishment of the royal initiatives in the border areas was the appropriation of the US and Thai military governments' counterinsurgency programmes and mobilising them to consolidate both the border and rural populations under a royalist nationalism at the height of the Cold War.

\section{Royal Mother from the Sky}

According to the BPP's accounts, the Princess Mother made a total of 267 official royal visits to BPP-related events between 1963 and 1991. While the regional distribution of her trips to BPP-related events are quite balanced among the four regions, it is noteworthy that 263 out of 267 trips were made before 1980, as we can see in figure $1 .{ }^{57}$

54 Raymond Coffey et al., 'Contractors semi-annual report, Devcon Development Consultants in support of Border Patrol Police Remote Area Security, August 1968-January 1969' (Bangkok: USOM, 1969); Interview, Manas Khantatatbumroong, 3 Dec. 2009.

55 Bhisatej Rajani, Khrongkan tangtang thi damnoen kantam phraratchadamri [Various projects implemented by the Royal Project] (Bangkok: Hanghunsuan jamkat nonthachai, 1976), pp. 57-68. Mom Chao Bhisatej Rajani was the first coordinator of the royal development project. See also Chanida, Khrongkan annueang ma chak phraratchadamri, pp. 6-7.

56 Quoted in Bhisatej Rajani, 'His Majesty's assistance to hill tribes' (mimeo, 1970), p. 2.

57 This information is compiled from the list of the Princess Mother's visits in BPP HQ, Tochodo sadudi 100 pi, pp. 209-23. 


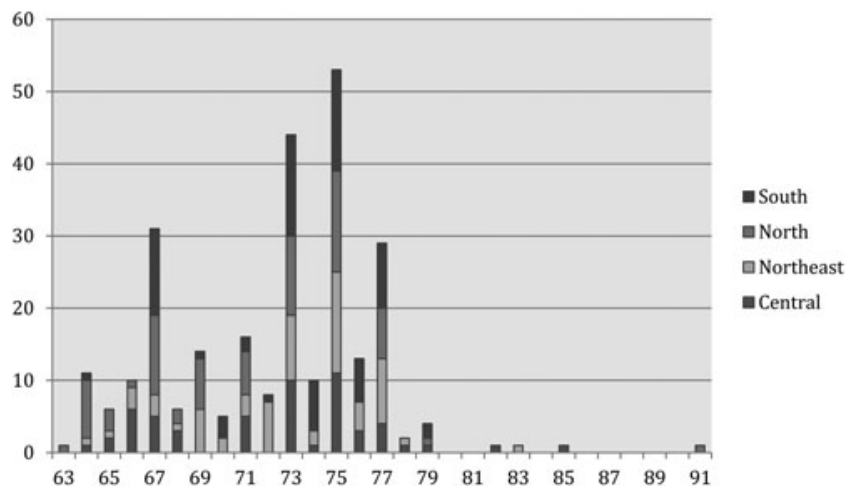

Figure 1. The Princess Mother's royal visits to the BPP-related events, 1963-1991 (267 visits)

Source: BPP HQ Headquarters, Tochodo sadudi 100 pi somdetya [BPP Honour the hundredth anniversary of the birth of the Princess Mother] (Bangkok: Chulalongkorn University Press, 2000), pp. 209-23.

The Princess Mother's visits consisted of school openings, donating supplies to the BPP personnel in area camps, and, after 1971, Village Scout initiations. The Village Scouts is a civilian, non-traditional scout organisation initiated by the BPP in 1971 and whose patron was the royal family ${ }^{58}$ Her visit to BPP schools constitutes more than half of the total visits (140 times), and her attendance at Village Scouts initiations (85 times) ranks second. As shown in figure 1, the Princess Mother's visits were most intensive in the years 1967 (31 times), 1973 (44 times), and peaked in 1975 (53 times). In 1967, 11 out of 31 trips were made to open new BPP schools in northern Thailand. Considering the fact that she only made a total of ten visits in the previous year, tripling the number of the Princess Mother's royal trips in 1967 corresponds to the rapid increase of BPP school building in the north. As the ethnic minority insurgency escalated in the north, the BPP accelerated and expanded its programmes by building more schools and initiating new projects like the BSVT in 1967. In addition, this is also the year that the Princess Mother officially became a royal patron of the Bordercraft project.

Other distinguishable timings are 1973 and 1975, when the number of trips peaked. One notable difference between 1973 and 1975 was her destination: in 1973, out of 44 trips, the Princess Mother visited 29 schools, but only 4 Village Scout initiations - one per region. In 1975, however, out of the total 53 visits, she attended 35 Village Scout initiations. The change in the frequency and destination of her royal trips between 1973 and 1975 is quite remarkable because it clearly shows where royal attention was invested at the time. Finally, it is noteworthy that the number of her royal trips dropped dramatically after 1977. The Princess Mother made 29 trips to the provinces to attend BPP-sponsored events in 1977,

58 See further Katherine A. Bowie, Rituals of national loyalty: An anthropology of the state and the Village Scout movement in Thailand (New York: Columbia University Press, 1997). 
but then the very next year she only visited 2 Village Scout initiations in Nakhon Nayok and Nakhon Ratchasima provinces, which are relatively close to Bangkok. In other words, the Princess Mother's royal trips took place in areas where there were security concerns, where the number of insurgencies grew, and where the presence of state authority was urgently demanded as part of the counterinsurgency campaign.

The Princess Mother did not go empty-handed. Usually, she brought school supplies, uniforms, books, toys, framed photos of the king and queen, and Buddha images to distribute to the students, as well as medicine, food, clothes, and transistor radios for the villagers. ${ }^{59}$ She also donated money to build or repair camp facilities. Two of the first BPP schools built under the Princess Mother's sponsorship were the Ananda Border Patrol Police School in Palau village, Prachuap Khirikhan province (apparently built in commemoration of her late son) and the Walai Border Patrol Police School in Hua Hin, to which she donated 110,000 baht (US\$5,288) in $1964 .{ }^{60}$ However, these schools are rare cases among the royal-sponsored BPP schools, in that they received direct funding from the Princess Mother. According to the BPP's own account, only ten schools were paid for by the Princess Mother alone and these - such as 'Sangwanwit' or 'Somdet Phraratchachonani' — are named after her. ${ }^{61}$ In most cases, the Princess Mother received donations from individuals or governmental and nongovernmental organisations to support the BPP's programmes in remote areas. ${ }^{62}$ In total, the royal family supported the building of 198 BPP schools by donating almost 16 million baht between 1962 and 2006; and 140 schools received full or partial support from the Princess Mother between 1963 and 1991.63

The royal projects have had a number of donors over the years, ranging from individuals to major business companies who have assisted the royal initiatives. Donors often obtain tax-deductions in addition to accruing merit through their charitable activities. Most of the royally sponsored non-profit foundations rely on donations and thus the money given to the BPP civic action programme 'through' the royal family has not been completely from royal pockets. One notable source of funding for the royal projects has been the Princess Mother's Charities Fund of Thailand, Inc. (PMCF). It is unclear when this non-profit corporation was established, but according to a former committee member it became an official royal foundation in November 1980 in celebration of the Princess Mother's eightieth birthday. ${ }^{64}$ For the first four years after its establishment, former Minister of Foreign Affairs and head of the Democrat Party, Thanat Khoman served as the president of the PMCF's committee. ${ }^{65}$ One major patron of PMCF, Betty Dumaine, was the Princess Mother's

59 BPP HQ, Duai chongrak lae pakdi hasippi rongrian tochodo [50 loyal years of the BPP School] (Bangkok: BPP HQ, 2006), p. 114.

60 BPP HQ, Tochodo sadudi 100 pi, p. 210; BPP HQ, Duai chongrak lae pakdi, p. 112.

61 BPP HQ, Duai chongrak lae pakdi, pp. 84-5.

62 For example, see ibid., pp. 86-8, for the list of schools that received external donations through the Princess Mother.

63 Ibid., pp. 89, 113.

64 Sangwon Krairoek, 'Munithi kongthun kankuson somdetphra sinakharindra boromratchachonani, chai chue yoh PMCF [The Princess Mother's Charities Fund of Thailand, Inc. or in abbreviation, PMCF]', Tamruat trawen chaidaen parithat 11, 38 (Oct. 1994-Jan. 1995), pp. 54.

65 Sangwon, 'Munithi kongthun kankuson somdetphra', pp. 54-5. 
lifelong friend. A classmate of the Princess Mother in Boston in 1919, Dumaine conceived of a non-profit organisation that could financially support her royal friend's projects in Thailand and thus established the PMCF in Pinehurst, North Carolina. The PMCF also attracted several noteworthy figures, like Lieutenant General Richard G. Stilwell, commander of the US Military Assistance Command in Thailand from 1965 to 1967, and the head of the B. Grimm Group in Thailand, Herbert Link, who later offered one of his office buildings to the PMCF on a rent-free basis. ${ }^{66}$

One of the first projects that the PMCF undertook was rebuilding the Betty Dumaine BPP School in Chiang Rai province that had been allegedly burnt down by communist terrorists. Dumaine brought US $\$ 50,000$ in 1967 to reconstruct the school building. ${ }^{67}$ After an official branch of the foundation was set up in 1980 on Sathorn Road, Bangkok, the PMCF set a goal to sponsor five other charity organisations' activities: Aid for Border Patrol Police, Aid for the Crippled, New Life Foundation, Aid for Lepers in Lampang province, and the PMMV. Through to the present, the donations from PMCF have continued to flow to BPP schools, including student grants called the 'Princess Mother's Scholarship'. ${ }^{68}$ To show her appreciation, the Princess Mother bestowed on Betty Dumaine the honorific title of 'than phuying', the highest conferred non-inheritable lifetime title for a non-royal woman in Thailand. Soon, stretching from the experience with the PMCF, there emerged numerous non-profit organisations such as the Mae Fah Luang Foundation and Princess Srinagarindra Award Organization under the Princess Mother's royal patronage of BPP programmes. ${ }^{69}$

There were also a number of local support groups for the Princess Mother's cause. One notable group that had begun supporting the BPP's civic actions from the early years is the Thai Women's Society. ${ }^{70}$ Before Phao Siyanon moved to the TNPD, his wife Udomlak Siyanon, daughter of the military leader Phin Chunhawan, had served in the Committee of the Thai Women's Society. After she became the head of the Society in 1954, Udomlak extended the Society's charities to the BPP school projects by donating money and school supplies until 1957, when she left for Switzerland after Sarit's coup. ${ }^{71}$ A year after Phao's death in Switzerland, Udomlak returned to Thailand in 1961 and resumed her charitable activities. She served again in the Committee of the Thai Women Society from 1975 until

66 'Princess Mother's Charities Fund of Thailand, inc.' (pamphlet in English, n.d.). The Link family, who are German, owns one of the oldest companies in Thailand; Herbert Link's ancestors were official pharmacists to the Thai royal family since the late nineteenth century. Harald Link, Herbert's nephew, is the chairman of the PMCF Foundation as well as the B. Grimm Group in Thailand. See http://www. bgrimmgroup.com/en/index.php (last accessed 3 Sept. 2015).

67 Sangwon, 'Munithi kongthun kankuson somdetphra', p. 57; 'The history of the Betty Dumaine School History', Powerpoint presentation by school principal, 3 July 2010, Phayao province.

68 Sangwon, 'Munithi kongthun kankuson somdetphra', p. 54.

69 See 'Mae Fah Luang Foundation under Royal Patronage', http://www.maefahluang.org/index.php? lang=en (last accessed 3 Sept. 2015); and 'Princess Srinagarindra Award Organization', http://www. princess-srinagarindraaward.org/en (last accessed 3 Sept. 2015).

70 Manas Khantatatbumroong, 'Rongrian chaokhao lae prachachon klai khamanakhom' [School for the hill tribes and people far from communication], in BPP HQ, Kong banchakan tamruat, p. 232.

71 Anuson ngan phraratchathan phloengsop khun ying udomlak siyanon pomo, thocho, na wat phra si mahathattu wan angkhan thi 29 thanwakhom phoso 2524 [Cremation volume for Khun Ying Udomlak Siyanon, 29 Dec. 1981] (n.p., 1981, unpaginated). 
her death in 1981. According to the memoirs of former commissioners of the BPP and TNPD, Udomlak also actively supported welfare services for the Thai police alongside her generous support for BPP activities, especially the Princess Mother's 'Building Security in the Rural Villages Project'. ${ }^{72}$

In addition, numerous social organisations both at home and abroad such as the Red Cross in Thailand, the Faculty of Medicine in Siriraj Hospital and the Young Buddhist Association of Thailand have been making donations to the royal family to be conveyed to BPP civic action programmes. ${ }^{73}$ Also, major business companies like Siam Cement and Osotspa Co. Ltd., and popular figures like Thanom Kittikachorn and US ambassadors to Thailand gave personal donations to the Princess Mother. ${ }^{74}$

All this financial and material support to improve the BPP's services in the remote borderlands and rural areas has been a collective effort by various social, political and business groups to develop Thailand's margins, but, predictably, it is the royal family who have gained popular attention and affection. In the eyes of the public and also the BPP, these organisations and public figures have made merit by donating money to the monarchy, and the royal family have generously bestowed these resources to the royal projects and other charities to help people in need. This donation cycle in fact derives from a significant Buddhist tradition of 'merit-making' (tham bun). In Thai society, it is believed that donating to people in high places will accrue greater merit for the giver, and thus the royal projects or royally sponsored organisations have received continuous, stable support from the general populace. As a consequence, the collective support given to royal projects and to BPP programmes from the various social, business and political organisations all the more signified the devotional and people-oriented images of King Bhumibol and the Princess Mother.

The Princess Mother in her BPP fatigues and beret travelled tirelessly to the remotest corners of northern Thailand between 1964 and 1978 to distribute modern goods and medicines to ethnic minority people. Most of these kan sadets were made with the BPP by helicopter because the villages were generally in fairly inaccessible areas. According to a former PSD adviser, all these helicopter rides were facilitated by companies hired by the CIA like Bird \& Sons Inc. (Bird Air), Continental Air and Air America; moreover the CIA under its USOM cover paid for the fuel and other trip expenses. ${ }^{75}$ It was these helicopter trips that gave birth to the legend of Mae Fah Luang according to the eponymous foundation:

Mae Fah Luang is the title given to Princess Srinagarindra [Sinakharinthra] by the hill tribe people in the north of Thailand. Since the late 1960s, the Princess Mother worked to improve the living conditions of rural Thais, particularly the ethnic minorities in remote mountainous areas that were only accessible by helicopter. ... It was this very image of the Princess Mother descending from the skies that gave rise to the name

72 Ibid.; BPP HQ, Anuson phon tamruat ek wiphat wipunlakon, p. 85.

73 Manas, 'Rongrian chaokhao lae prachachon klai khamanakhom', p. 5.

74 Dumaine and Layton, Somdetphra boromratchachonani, pp. 48-9; Manas Khantatatbumroong, 'Kan songkhro chaokhao nai phak nuea khong tamruat phuthon chaidaen' [Welfare and management activities of the Border Police among the hill tribes in northern Thailand] (MA thesis, Thammasat University, Bangkok, 1965), pp. 12-13.

75 Interview, Gordon Young, 14 Mar. 2012. 
'Mae Fah Luang' (meaning Royal Mother from the Sky) and became the affectionate title by which the local people address the Princess Mother. ${ }^{76}$

The commemoration volume for the Princess Mother sponsored by her granddaughter Princess Sirindhorn in 1998 provides some possible origins for the name. Its author, Supharat Loetphanitkun, concludes that it was the BPP who coined the name around 1967. Supharat begins with questioning the unusual combination of 'sky (fah)' and 'royal (luang)'. 'Mae' (mother) 'fah' and 'luang' are Central Thai words and luang has been conventionally used to imply a sovereign ruler both in central and northern Thailand. However, since the combination of 'sky' and 'royal' is not common in regular Thai royal discourse, Supharat hypothesises that the BPP translated the highland minority's vocabulary for a ruler (from the heavens) into the Thai equivalent word 'sky' and attached it to the general Thai term 'luang. ${ }^{77}$ Or it may have simply been a continuation from the titling of previous royal projects. The BPP schools built with the king's donations were named 'Chao Pho Luang' and those of queen's as 'Chao Mae Luang' in the early 1960s. Therefore, when the Princess Mother began to sponsor the BPP School project, the BPP members created the title 'Chao Mae Ya Luang', meaning the royal paternal grandmother, but as the villagers did not use the term much, it soon disappeared. ${ }^{78}$

Notwithstanding this elaborate explanation, the populace, Thai and non-Thai alike, however, still call the Princess Mother 'somdetya' (which might have been also created by the BPP). It is the mythical power of legend mostly consumed by outsiders like the Bangkokians that make the 'Mae Fah Luang' story popular and credible. In this sense, it is a purposeful legend created to exalt the Princess Mother as royal mother of the highland minorities in the eyes of the general Thai populace. More importantly, the continuous creation of the legendary endeavours of the Princess Mother and the royal family as saviours of the Thai people indeed contributed to transforming the traditional monarchy into a modern institution, and the creation of an almost sacred and thus irreproachable royalist nationalism.

\section{Conclusion: Cold Warriors moving into the post-Cold War}

What was the impact of the Princess Mother's extensive involvement with the Border Patrol Police on the institution of the Thai monarchy? The Princess Mother's work with the BPP had two significant legacies. First, she attempted to bring marginalised people into the centre of Thai society, and supplied the legend of the royal saviour. As a commoner herself who had married a prince and given birth to two kings of Thailand, her life story was already the 'script for a fairy

76 Mae Fah Luang Foundation, 'Founder', http://www.maefahluang.org/index.php?option=com flexicontent\&view=items\&cid=19\&id=2\&Itemid=8\&lang=en (last accessed 3 Sept. 2015).

77 The author, Supharat Loetphanitkun did not specify the ethnic group. It is presumable that because the monarchy uses the term chaofa, lord of the skies, or 'His Royal Highness' in the titles, the BPP might have followed suit and added 'sky' (fah). Phrama malaisokla lueangsuk: phrarat prawat lae phrarat koranikit nai somdetphra sinakharindra bromratchachonani [After Princess Mother came, sadness disappeared and happiness remained: Royal histories and duties of Her Royal Highness Princess Mother], ed. Supharat Loetphanitkun (Bangkok: Krungthep Press, 1984), pp. 562-4.

78 Supharat, Phrama malaisokla lueangsuk, pp. 562-4. 
tale'.$^{79}$ On top of this humble commoner background, her tireless commitment to opening 'a path to civilization for remote border villages' created the image of the Princess Mother and the royals as saviour(s) from the sky. ${ }^{80}$ Often, this royal effort to bring the highland minorities into the Thai nation was interpreted by the general population as the generosity and genuine sympathy of the monarchy for the marginalised, to whom other Thai state apparatuses seemed to remain indifferent.

The Princess Mother did extend her compassion to these alienated people and initiated a number of royal projects for them, but it should also be noted that in the process she harnessed the ethnic minorities' 'otherness' in her development projects to elevate the authority and popularity of the monarchy. Her legacy to the Thai ruling elite's ambivalent treatment of ethnic minorities has become more evident today, when minorities in the borderlands are utilised by the elites to promote tourism while demonstrating the royal family's long-standing endeavours to bring 'civilisation' to the margins. ${ }^{81}$

Second, the Princess Mother created a source of political authority as well as legitimacy for King Bhumibol through her support for the BPP in northern Thailand which became the foundation for the king's first official royal project in 1969. The king began to build his political influence on the basis of his mother's work by presenting himself as the 'development king' from the mid-1960s. ${ }^{82}$ Prior to this, the king had been known for his talent in music, painting, sports and for a gentle, charming demeanour as projected through massively reproduced photographs and film footage. Amid the escalating tensions of the Vietnam War and in rural Thailand from the mid-1960s, these images were replaced by the photographs of the king who fearlessly travels to the dusty countryside with a camera around his neck instead of a saxophone, sweating over maps and advising government officials, showing the deepest concern for his people's welfare and the nation's development. ${ }^{83}$ In his mother's footsteps, he travelled to remote border areas and opened schools and medical clinics for the ethnic minorities, and began playing the role of the father of the nation who brings development to the poor rural areas. In this respect, the Princess Mother's work contributed to laying the groundwork for the revival of the Thai monarchy as an institution, both as a traditional patron of the nation and a modern, professional state apparatus.

In sum, through her participation in the BPP's programmes, the Princess Mother constructed the symbolic images of a royal mother who cared about the marginalised,

79 Tom Mintier, 'The fairy tale life of the Thai royal grandmother', Cable News Network, 28 Oct. 1995, reprint. in FCCT, The King of Thailand in world focus, p. 194.

80 Layton, 'Royal Mother from the Sky', p. 7.

81 See in particular, the Doi Tung Development Project website, http://www.doitung.org/home.php (last accessed on 6 May 2016). On ethno-tourism and the Thai government's othering of ethnic minorities, see, for example: Jean Michaud, 'A portrait of cultural resistance: The confinement of tourism in a Hmong village in Thailand', in Tourism, ethnicity, and the state in Asian and Pacific societies, ed. Michel Picard and Robert E. Wood (Honolulu: University of Hawaii Press, 1997), pp. 128-54; Hayami Yoko. 'Negotiating ethnic representation between self and other: The case of Karen and eco-tourism in Thailand', Southeast Asian Studies 44, 3 (2006): 385-409.

82 Chanida, Khrongkan annueang ma chak phraratchadamri, pp. 140-41.

83 On Bhumibol's changing image between the 1950s and 1960s, see Handley, The king never smiles, pp. $180-93$. 
and expanded her royal projects to cover education, health and sanitation, rural economic development, and also border security projects, which became the mechanism for propagating royal benevolence and professionalism. Throughout the process of expanding her royal projects from the northern border areas to the entire country with the BPP's assistance, the Princess Mother also played a crucial role in modernising the monarchy and enabling her son, Bhumibol, to become the father of development and royal nation-builder during the Cold War. In this process, the Princess Mother secured the BPP's existence too. Because of her vested interest in expanding the royal projects with the BPP's assistance, the Thai military government could not express its suspicions and hostility toward the paramilitary unit. In 1972, Thanom Kittikachorn finally endorsed the reinstatement of the Border Patrol Police Headquarters and separated the organisation from the Provincial Police. ${ }^{84}$

In hindsight, the king could not have become the development king and the Father of the Thai Nation without these lesser-known endeavours of a 'network monarchy', and the Princess Mother indeed played a pivotal, transformational role in this network during the Cold War. ${ }^{85}$ She strategically chose the BPP to expand her royal projects and deepened the image of the monarchy as modern, professional and benevolent in the eyes of the Thai people.

The legacies of the Princess Mother's work are still visible. As she commanded Princess Sirindhorn to take over her work, Sirindhorn has been in charge of the BPP schools project since 1980. Princess Sirindhorn has inherited almost an identical image to that of her grandmother, and has become the most beloved member of the royal family. Meanwhile, Princess Galyani, Bhumibol's elder sister, took over the PMMV and acted as royal patron for general Thai medical studies and practices following her mother's example. When Princess Galyani passed away in 2008, she was a direct royal patron of 63 social organisations and foundations in support of education and public health. ${ }^{86}$ At present, Bhumibol's youngest daughter, Princess Chulabhorn Walailak, has become PMMV's royal sponsor. In addition, even though the Princess Mother passed away over two decades ago, numerous organisations and foundations initiated under her patronage including the BPP are still flourishing with newer royal sponsors. The BPP, in turn, has become a symbolic missionary of royalist nationalism throughout Thailand's border areas, and is still actively developing its civic action programmes to bring modernisation and development to the marginalised. Unlike other CIA-sponsored and initiated paramilitary forces during the Cold War, this Thai cold warrior is living up to its post-Cold War mission of spreading royalist nationalism as well as consolidating the border peoples under royal patronage.

\section{Postscript: Border Patrol Police remember the Royal Mother}

To show their deep appreciation of the BPP, the royal family bestowed them with an official theme song, the Border Patrol Police. According to a Bangkok Post reporter,

84 BPP HQ, Kong banchakan tamruat trawen chaiden thiraleuk nai kanpoet akhan bor chor BPP, p. 114.

85 Duncan McCargo, 'Network monarchy and legitimacy crises in Thailand', Pacific Review 18, 4 (2005): 505.

86 Welcome to Chiang Mai and Chiang Rai, 'Thailand's beloved Princess', http://www.chiangmaichiangrai.com/thailands-beloved-princess.html (last accessed 3 Sept. 2015). 
it was the queen who wrote the lyrics and gave the song to the BPP. ${ }^{87}$ In fact, Than Phuying Manirat Bunnag, Queen Sirikit's aunt and lady-in-waiting, had composed the lyrics, to the tune of the Irish folk song Danny Boy. ${ }^{88}$

While it might have been the queen who actually commanded her lady-inwaiting to compose the song for the BPP, those whom I had met and interviewed for about two years in Thailand remembered quite differently. They unanimously said that it was the Princess Mother who gave them a theme song to console them for their hardship in the remote jungles and to make Thai people know about the BPP's sacrifices, because the royal grandmother was the person who had truly devoted herself to help and protect them. This is a telling example of how the BPP has always praised and continues to praise the Princess Mother's role. The BPP Headquarters' radio station still plays the song every day at noon, reminding its listeners that the BPP is still a child of the Royal Mother from the Sky.

87 Amporn Tantuvanich, 'Only the gun and the moon for company', Bangkok Post, 29 Jan. 1979.

88 BPP Support Division, 'Phleng amata prathapchai' [Songs that are everlastingly satisfying], from the Annual Meeting of the BPP General Headquarters, Sinakharinthra Dam, Kanchanaburi province, 23-26 Nov. 1998 (Bangkok: BPP, 1998), p. 10. 